\title{
Examining Success of Land Record Information Systems (LRMIS) in Pakistan: Validating an incorporated IS success model
}

\author{
Babur Hayat Malik \\ Cai Shuqin
}

School of Management,

Huazhong University of Science and Technology, Wuhan China

Saqib Qamar

School of Computer Science and Technology,

Huazhong University of Science and Technology, Wuhan China

\section{Butt Mattiullah}

School of Management,

Huazhong University of Science and Technology, Wuhan China

doi: 10.19044/esj.2016.v12n2p258 URL:http://dx.doi.org/10.19044/esj.2016.v12n2p258

\begin{abstract}
Objective of this article is to investigate the success (by determining citizen's intention to use and satisfaction) of Land Record Information Systems (LRMIS) from perspective of Pakistan. The success of this egovernment information system is investigated using an incorporated IS success model. Model formulated here features constructs such as System Quality, Service Quality, and Information Quality, Perceived Risk, Perceived Ease of Use, Perceived Satisfaction, Perceived Usefulness, Awareness, Trust, Information Security and Behavioral Intention. The suggested incorporated research model of IS was validated using feedbacks taken from 250 citizens across different cities of Pakistan. Verifiable findings showed the positive and substantial linkage between all 17 hypothesized associations of 10 different constructs. Validated data-based outcomes and argumentations provided in this research can help government to enrich upon and to completely avail the potentiality of LRMIS as serviceable and an effective computer system toward a digital, secure, lucid and uncorrupted society.
\end{abstract}

Keywords: Land Record Information System LRMIS, E-government, DeLone and McLean, Seddon, Pakistan 


\section{Introduction}

In beginning of 1990s, due to rapid developments in information and communication technologies (ICTs), huge and brisk changes in the daily life of citizens and governments happened and observed (Dwivedi et al. 2008; Floropoulos et al. 2010). Recognizing this technology evolution, governments across the globe are desalinizing into new forms of government called electronic government (hereafter, e-government) (Akman et al. 2005) to bolster up and uphold their positions in the global competition (Sharifi and Zarei 2004).As e-government serves up many benefits to governments, professionals, and organizations, it is citizens who actually outguessed to acquire a number of benefits (Jaeger 2003).

The most noteworthy demand of citizen's digital daily life such as preserving their Land Records at state and country level of government in a country like Pakistan is very much needful and obvious. Always a need of assessment endeavors that could examine their effectiveness, as governments develop e-government systems to provide services to their citizens (Wang and Liao 2008).Land Record Information System (LRMIS) is one such egovernment system, which is principally planned and designed To preserve the land records, transfer and other issues related to smoothness of land records. Actual aim of the Project is to reform the land records services to deliver in the Province of Punjab, while being contributive to long-lasting tenure security. The results which are expected from the Project are:

1. Increased access to land records at lower transaction cost for the beneficiary, through a client-responsive service.

2. Increased level of tenure security of land-right holders.

Success will be assessed by client satisfaction with the new system, in terms of access to records and increased level of tenure security and by measures of improvement in services (reduced time for issuance of fards and completing mutations). Although the Project aims at benefiting the entire community of landowners, a specific target will be the underprivileged and marginal groups that are penalized by the existing land recording system. Specific measures for participation by women and subsistence farmers will therefore be monitored. A results and key performance indicator framework in line with the development objectives of the project has been developed (Lrmis 2015).

As, the LRMIS provides above mentioned benefits, its adoption is currently low and at initial stage. The purposefulness of such e-government systems is found to be even more for secure, smooth, transparent and digital driven governments. Moreover, as the government has implemented this egovernment system in Punjab Province, its success could be realized in a real sense by citizen perspective so as to adopt similar kind of systems in other provinces .Such systems could be perceived as primarily successful when 
users consider it as an indispensable tool for securing their land record and its usefulness. Due to lack of technology built infra-structure, low adoption rate and less awareness, previous literature has no specific investigations to find the success of such an important public administration system. It is obvious from the argumentation discussed above that it would be useful to assess success of the LRMIS by validating an integrated IS success model. Dwivedi et al. (2012) investigated that DeLone and McLean (1992, 2003) IS success models are among few such models that have assisted researchers to set up some of the prominent elements that impact the favorable reception and use of e-government services by citizens before testing and post adoption. To measure the success of the LRMIS, this article has validated the integrated model of IS success by blending the constructs from Seddon (1997) and Delone and McLean (2003) IS success models joined with some additional constructs including perceived ease of use and perceived risk. The construct, perceived trust not being added in the proposed model is because of the fact that trust is just a substitute variable for risk and determines the reverse of the coded items and adverse influence intentions (e.g. Carter et al. 2011; Karavasilis et al. 2010) in few prior studies of e-government systems adoption. The leftover part of this article is structured as follows: the next section describes a review of e-government literature based on IS success model, followed by a concise elaboration on the utilized theoretical background of DeLone and McLean (1992, 2003) and Seddon (1997) IS success models. Section 4 illustrates a summary of the proposed research model and vindication for the proposed hypotheses followed by a brief discussion on utilized research method. In Section 5 and Section 6, results and outcomes are addressed respectively. At the end, In Section 7, the conclusion including limitations and future research directions and implications for theory and practice are described.

\section{Literature review}

Research studies (e.g. Chai et al. 2006; Chen 2010; Floropoulos et al. 2010; Gotoh 2009; Hsu and Chen 2007; Hu et al. 2009; Rana et al. 2013b, c; Sambasivan et al. 2010; Scott and DeLone 2009; Teo et al. 2008) have used IS Success Models to investigate the use, intention to use, and satisfaction toward adopting an e-government system. Many citizen-centric digitally designed and improved services employed by governments of various countries including Pakistan in present times. In government formulating such e-government systems to offer such improved services to people, more critical analysis and efforts are required to determine the effectiveness and usefulness of the e-government systems. The assessment endeavor would let government agencies to identify whether they are competent to serve what 
people really need and offer them expected services therefore (Gupta and Jana 2003; Wang and Liao 2008).

After dissection of research outcomes of the different literature studies, Chai et al. (2006) expressed that the success of e-government relies on how governments provide high quality and user-oriented e-government services to its people. Government websites were jointly one of the major factors of the success of the e-government digital paradigm shift. The affiliation between the quality of websites and their success has been inspected in some research studies (Chai et al. 2006). Palmer (2002) addressed that quality of a website can be determined by its connection speed, interactivity, navigability, responsiveness, and quality substance. Reasonably, it was discovered that website quality is obligated to have positively linked toward developing trusting intention on e-commerce website (McKnight et al. 2000). Hence, website service quality can be reckoned as one of the strongest mediators of e-government success and user's intention to permanently use an e-government website (Chai et al. 2006). Scott and DeLone (2009) described a multi-faceted framework to grasp the success of e-government websites from the people's perspectives. They constituted the capacity of net rewards in the assessment of egovernment success and extended the knowledge of e-government success by investigating the influence IT quality constructs. Investigating adoption of the electronic procurement system, Sambasivan et al. (2010) broadened the DeLone and McLean's IS success model using additional factors including trust, facilitating conditions, and web-design quality and proved them strongly linked to intention to use. The outcomes prefigured that perceived ease of use, perceived usefulness, assurance and responsiveness of service by service providers, web design (service quality) and facilitating conditions strongly linked to intention to use electronic procurement system.

Investigating the e-government system in Taiwan, Hsu and Chen (2007) gave a substitute approach of the IS success model to observe the IS use behavior by indicating that user's intention to use an IS in e-government is regularized by social (i.e. normative pressure) and functional value (i.e. information and service quality) rather than conditional value (i.e. system quality) and satisfaction. Teo et al. (2008) have investigated the impact of trust on the specific e-government systems on the quality constructs (i.e. information, system, and service quality) of the IS success model by arguing that higher level of people's trust has positively relations with system quality, information quality, and service quality of the systems (Teo et al. 2008). Researching IS success model, Wang et al. (2010) formulated a model for citizen's sustainable trust in e-government. Opposing to Teo et al. (2008) conceptualization, Wang et al. (2010) reckoned that higher levels of system quality, information quality, and service quality would direct to citizen's 
improved trust on an e-government system, resulting in positive intentions to use the system. Moreover the study has not conducted any empirical investigation of the proposed research model while showing that literature that trust is very highly correspond with the quality constructs either in the form of a determinant or as a dependent variable not investigating risk related issues. Investigating the success of online taxation systems has been observed as a usual work across e-government research in the some past studies. Gotoh (2009) dissection of the online tax declaration services for the Japanese government and empirically inspected it to unfold factors that improve user's satisfaction with these kinds of digital services. The article proposed IS success models with two changeovers where preparation quality and result quality were the constructs using aside from system quality, which was driven from the IS success model. In context of Hong Kong, $\mathrm{Hu}$ et al. (2009) investigated the determinants of service quality and continuance intention on the e-Tax system. The data dissection assisted both service traits (i.e. convenience and security) and one technology trait (i.e. perceived ease of use) as the main decisive factors of the service quality. They examined that service quality was strongest predictor of continuance intention but perceived usefulness was not. In context of Taiwan, Chen (2010) Investigated taxpayer's gratification with the online system for filing the individual income tax returns, observing its information quality, system quality, and service quality, which are determinants of user's gratification with any such system. Considering DeLone and McLean's IS success model, the author explained how the use of the system would be increased by the enhancing software gratification with it, discovering that how system quality and information quality are significant components to get this aim. Floropoulos et al. (2010) examined the success of the Greek taxation information system from the perspective of skilled employees using the constructs including system quality, perceived usefulness, information quality, service quality, and user satisfaction and observed the stiff relationships between five success constructs, while observing the impact of system quality on perceived usefulness very low and on user gratification as non-significant. But none of them have tried to justify service quality and perceived risk as part of their proposed research models. Measuring the credibility of IS success models for the OPGRS system, Rana et al. (2013b) proposed that system quality and information quality noteworthy impacted both user gratification and behavioral intentions. The research discussed an integrated IS model and explained that the construct such as trust in addition to the quality constructs (i.e., system quality, information quality) produce the more vigorous model than any of the three individual mostly known and used IS success models such as DeLone and McLean's $(1992,2003)$ and Seddon's (1997) models. Rana et al. (2013c) utilizing Seddon’s (1997) 
model to grasp determinants affecting adoption of and gratification by usage of the system.

The research in this area has shown the intended outcome where quality corresponding constructs been hugely observed vital on intentions to use these kind of systems. Floropoulos et al. (2010) discovered that nonsignificant effect of system quality on intention to use the system as answerers were skilled to use it and quality of system did not affect their decision making competence. A few e-government systems have integrated perceived risk and assessed its effect on user's behavioral intentions. Very few articles on e-government adoption have investigated the vital roles of perceived ease of use and system quality. Our investigation observed system quality is just a subset of user's overall perception of ease of use of the system as associated to its quality such as quality of user interface, minimal bugs, and quality of specification and computer program code designed for the system. Few IS/IT researches (e.g. Lederer et al. 2000; Liao and Cheung 2001; Ahn et al. 2007) have clearly observed and discussed these constructs and their mutual relations. Rai et al. (2002) proposed the credibility of an IS success model discussing ease of use rather than system quality as a construct while observing and investigating the success of an integrated student information system. The unambiguous relations assessment and past investigations of perceived ease of use and system quality has develop a base to use these two distinguishable constructs in this proposed research model.

\section{Research model development and hypotheses: \\ Theoretical background-IS success models}

Three theories or models in the area of IS Success are most renowned. The first IS success model was proposed by DeLone and McLean (1992) with six factors namely information quality, system quality, use, individual impact, user's satisfaction, and organizational impact (DeLone and McLean 1992).Discussing articles (such as Seddon and Kiew 1996) pointing to few of its constructs such as organizational impact, individual impact, and use, Seddon (1997) proposed a re-validated model of DeLone and McLean (1992) assigning system as thought to produce the outcome of different kinds, perceived usefulness was positioned in the model as an IS measure. In 2003, DeLone and McLean addressed a lot of the substantial IS research contributions proposing more improved model. The improved IS success model (DeLone and McLean 2003) integrated a new construct 'service quality' and replacement of the variables, organizational impact and individual impact, with net benefits with accounting for benefits while investigating at different levels. 


\section{Overview of proposed research model for examining success factors of LRMIS}

The theoretical elaboration is derived by above described IS success models (DeLone and McLean 1992; 2003; Seddon 1997).Due to some specific rational observations, we did not add certain constructs of such models for our proposed model in this article. The construct 'use' was also not included from the proposed model as answerers of this research were prospect adopters ('not genuine users') .They have not been involved in any usage of the system but were described the functions of the system and its real advantages and in the future they are supposed to use this system, From the Seddon's (1997) model, perceived usefulness was replaced by the construct use. Seddon and Kiew (1996) and Seddon (1997) reasoned that inutility of a system does not signalize that it is not useful; merely, it may point out that prospect users have some other assignments to do (Seddon 1997; Seddon and Kiew 1996) .The addition of perceived usefulness as an proper construct in the proposed model, by rationalizing due to such legitimate evidences.

From DeLone and McLean's (2003) model of IS success a new construct called 'service quality' is included in proposed model. Petteret al. (2008) investigated that Service quality is basically associated with determining the quality of service gained by the IT departments in contrasting the particular IT applications. It mainly examines user's beliefs and their insight of IT department. Quantifying for service quality have been acquired from Pitt et al. (1995) who observed service quality revolved around the services supplied by the specified IS.As our research is all about services offered by LRMIS, it was reckoned proper to add service quality in this research model. The constructs like perceived risk and perceived ease of use were also conceived proper to be incorporated in the model as they indicate the users' speculation to handle the system recognizing its attached ease of use and associated risk in its usage. Hence, proposed research model (see Fig. 1) asserts that information quality and system quality will have a noteworthy impact on perceived satisfaction and perceived ease of use. A noteworthy impact of Perceived ease of use on perceived usefulness, perceived satisfaction and behavioral intention would be observed. Perceived usefulness and perceived risk will substantially effect behavioral intention. Service quality will substantially effect perceived satisfaction, who Demonstrates a substantially effect on perceived usefulness. Examining the supposed relations can assist to deduce the behavioral intention to use and success of LRMIS. 


\section{Hypotheses development}

The main constructs are described in Table 1.

Table 1: Descriptions of main constructs used in proposed model

\begin{tabular}{|c|c|}
\hline $\begin{array}{l}\text { Construct/ } \\
\text { Variable }\end{array}$ & Descriptions \\
\hline $\begin{array}{l}\text { Information } \\
\text { Quality }\end{array}$ & $\begin{array}{l}\text { Information quality is associated with the topics like the timeliness, relevance and } \\
\text { exactness of information produced by an information system. All type of } \\
\text { generation of information by applications of IT cannot be used for decision- } \\
\text { making (e.g., a word processor does not generate any information) so information } \\
\text { quality is not a scale that can be applied to all systems (Seddon 1997). } \\
\text { System quality is associated with presence of 'bugs' in the system, the uniformity } \\
\text { of the user interface, ease of use, documentation quality, and Sometimes program } \\
\text { code's quality and maintainability (Seddon 1997). } \\
\text { Service quality is associated with the quality of the assistance that users of system } \\
\text { get from the IS department and IT support staff. Such as, accuracy, } \\
\text { responsiveness, technical competence, reliability, and understanding of the staff. } \\
\text { A popular instrument for measuring IS service quality is SERVQUAL, varied } \\
\text { from the area of marketing (Pitt et al. 1995). }\end{array}$ \\
\hline $\begin{array}{c}\text { Perceived } \\
\text { usefulness } \\
\text { Perceived ease of }\end{array}$ & $\begin{array}{l}\text { Perceived usefulness is a degree to which an individual conceives that using a } \\
\text { particular system would improve his or her job performance (Davis, Davis 1989). } \\
\text { Perceived ease of use is the degree of which an individual reckons that using a } \\
\text { particular system would be free of effort (Davis 1989). }\end{array}$ \\
\hline Perceived risk & $\begin{array}{l}\text { Perceived risk is the individual's subjective anticipation of suffering a loss in } \\
\text { quest of a desired resultant (Warkentin et al. 2002). }\end{array}$ \\
\hline $\begin{array}{l}\text { Perceived } \\
\text { satisfaction }\end{array}$ & $\begin{array}{l}\text { Perceived satisfaction is the degree to which the user believes that the specific } \\
\text { system encircles his or her information demands (Ives et al. 1983). }\end{array}$ \\
\hline Awareness & $\begin{array}{l}\text { Awareness is, the degree to which users are aware of the portal. Kang and Lee } \\
\qquad(2010),\end{array}$ \\
\hline Trust & $\begin{array}{l}\text { User's willingness to rely on ( e-Government )service based on the feelings of } \\
\text { confidence or assurance. Kim et al. (2009), }\end{array}$ \\
\hline $\begin{array}{l}\text { Information } \\
\text { Security }\end{array}$ & $\begin{array}{l}\text { Citizens' perception of (e-Government) service as Secure and private without any } \\
\text { uncertainty or adverse consequences after e-Government use. Dixit and } \\
\text { Datta(2010), }\end{array}$ \\
\hline
\end{tabular}

17 hypotheses are formulated between 10 constructs (Behavioral Intention as Dependent Variable) mostly gathered from the IS success models (Seddon 1997; DeLone and McLean 1992, 2003) and additional constructs (such as perceived risk and perceived ease of use, awareness, trust) to investigate the effectiveness and importance of the relations. Development of each hypothesis is described in the following sub-sections. 


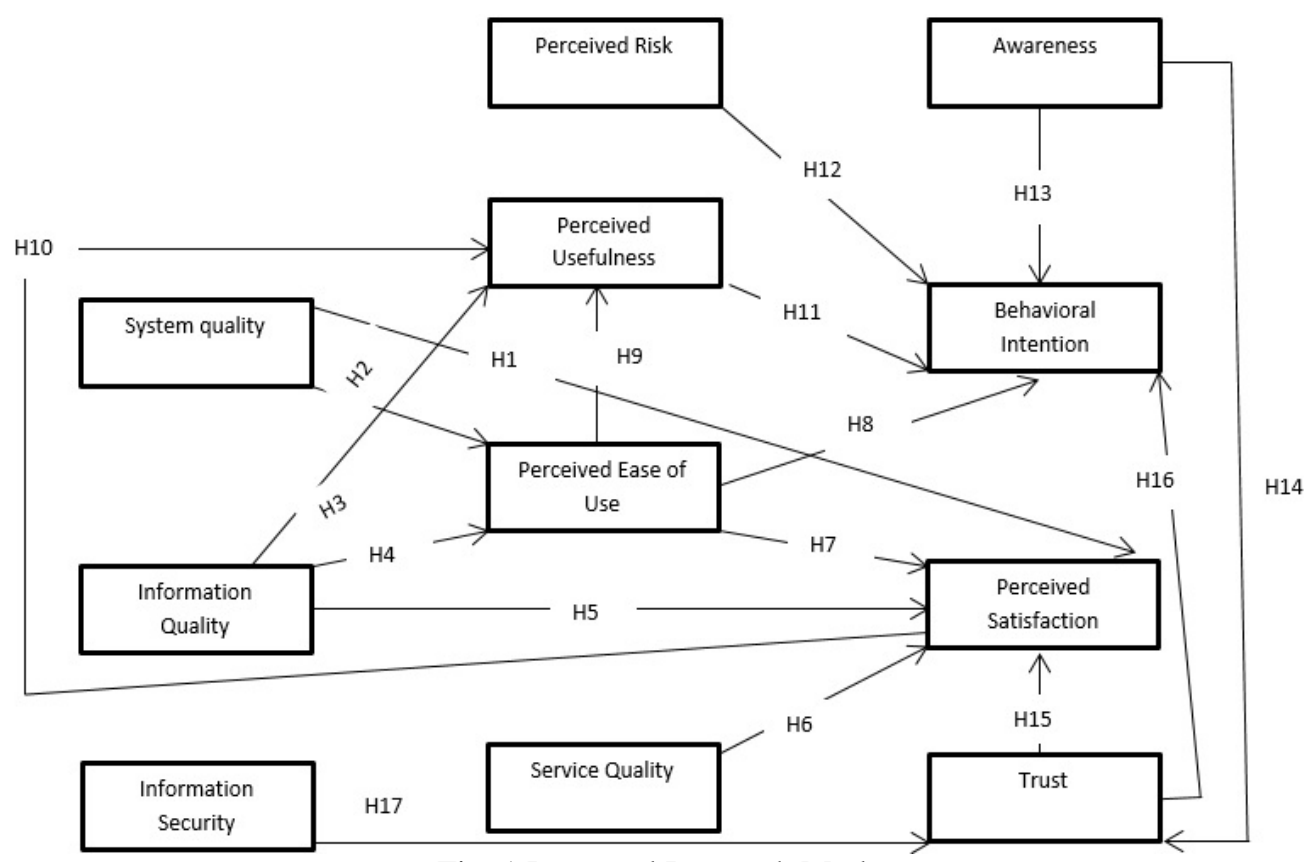

Fig. 1 Proposed Research Mode

\section{System Quality $\rightarrow$ Perceived Satisfaction}

System quality is accessed through the interaction with the system, when users complete a specific task (Maes and Poels 2007). DeLone and McLean (1992, 2003) described system quality as the wished aspects of the information system. They integrated 5 items into system quality: reliability, adaptability, response time, availability, and usability to examine the ecommerce success. Considering that higher system quality is presumed to lead to higher user satisfaction (DeLone and McLean 2003). Seddon and Kiew (1994) analyzed 104 users of a newly employed, university accounting system and discovered vital relation between system quality and user satisfaction. Researcher like (Seddon and Kiew 1996 ; Seddon 1997; Rai et al. 2002; ; Iavari 2005; Wang and Liao 2008; Dwivedi et al. 2013 ) have indorsed the positive and noteworthy impact of system quality on user satisfaction as explained in DeLone and McLean's model. Hence, we hypothesize:

H1: System quality has a positive and significant influence on the user satisfaction of the Land Record Information Systems (LRMIS).

\section{System Quality $\rightarrow$ Perceived Ease of Use}

System quality relies on the user's needs, as specified during the systems analysis and development. The systems related prospect proposes that hurdles to citizen acceptance are technology-oriented. High level of system quality would serve up consumers with more favorable, secured, and 
faster outcomes (Ahn et al. 2007). Lederer et al. (2000) and Liao and Cheung (2001) observed that such system's association-ness had a positive influence on the perceived ease of use of the related website. Investigating the acceptance of mobile Internet in Korea, Cheong and Park (2005) discovered that system quality significantly affected perceived ease of use of the relevant system. Investigating the user acceptance of the online retailing, Ahn et al. (2007) discovered that system quality had a positive effect on user's perceived ease of use. Hence, it is hypothesized that

H2: System quality has a positive and significant influence on the perceived ease of use of the LRMIS.

\section{Information Quality $\rightarrow$ Perceived Usefulness}

Seddon (1997) IS success model has assisted this relation, where they replaced 'IS use' of DeLone and McLean (1992) success model by perceived usefulness. Seddon (1997) discovered that perceived usefulness is influenced directly by understandings about information quality. Rai et al. (2002) discovered the positive and significant impact of information quality on perceived usefulness. Franz and Robey (1986), Kraemer et al. (1993) and Seddon and Kiew (1996) have also found that increased information quality leads to improved usefulness. Floropoulos et al. (2010) verifying the Seddon's (1997) argument discovered the impact of information quality on perceived usefulness in context of Greek TAXIS systems.

H3: Information quality has a positive and significant impact on perceived usefulness of the LRMIS.

\section{Information Quality $\rightarrow$ Perceived Ease of Use}

The information of the web is not only associated with the report but also to its user's reinterpretation (Ahn et al.2007). Frequently used determinations of web are its content and content quality (Ranganathan and Ganapathy2002).Previous researchers have found that high levels of information quality (i.e. various, timely, detailed, accurate, relevant, complete, and reliable) have a positive impact on perceived ease of use of a website (Ahn et al.2007). In case of e-government system, we also think that the relevance, timeliness, and accuracy of information generated by LRMIS will permit its users to use the system in an effortless way. Hence, we hypothesize:

H4: Information quality has a positive and significant impact on perceived ease of use of the LRMIS.

\section{Information Quality $\rightarrow$ Perceived Satisfaction}

Previous researches on IS success have exhibited assistance for the point that higher degree of information quality produces to raise user 
satisfaction (Chae and Kim 2001; Dwivedi et al.2013; Floropoulos et al. 2010; Iavari2005; McGill and Hobbs2003; Rai et al. 2002; Seddon1997; Seddon and Kiew1996; WangandLiao2008; Zhang et al.2005). Metaanalysis of DeLone and McLean model has also strongly assisted in impact of information quality on user satisfaction. Rana et al. (2013d) discovered by performing a meta-analysis between these two discussed constructs and traced the cumulative results as notables. E-government adoption studies, Wang and Liao (2008) showed and validated a specific model of egovernment system success (based on DeLone and McLean (2003) IS success model) and discovered the impact of information quality on user satisfaction being noteworthy assisted. Similarly, such outcome were gotten for TAXIS systems researched by Floropoulos et al. (2010) where the results showed system quality as a vital and strong determinant of employee's satisfaction. Meta-analysis of related information quality on user satisfaction also showed an important relation between them in context of e-government research area (Rana et al. 2012a, c, d.), we hypothesize:

H5: Information quality has a positive and significant impact on citizen's perceived satisfaction of the LRMIS.

\section{Service Quality $\rightarrow$ Perceived Satisfaction}

Previous studies recommenced including service quality as notable measure of IS success, due to the expanded part of the IS department and the significance of IS in the recent years (Chiu et al.2007; Dwivedi et al. 2010). DeLone and McLean (2003) described it as the full assistance provided by the service provider, and applies regardless of whether this assistance is delivered by the IS department, a new organizational unit, or outsourced to an ISP. Creating a multi-item index for e-service quality, Cristobal et al. (2007) discovered that perceived service quality significantly impacted buyers and information searcher's influence. Examining the success of Greek taxation information system, Floropoulos et al. (2010) found that service quality had a significant impact on user satisfaction. Wang and Liao (2008) also exhibited that there was a narrow assistance for service quality on user satisfaction while assessing the e-government systems success. Therefore, we hypothesize:

H6: Service quality has a positive and significant impact on citizen's perceived satisfaction of the LRMIS.

\section{Perceived Ease of Use $\rightarrow$ Perceived Satisfaction}

In South Korea, in context of the acceptance of the online learning tools in a university, previous studies has assessed perceived ease of use as important predictor of the user satisfaction (Joo et al. 2011). In researches related to e-government adoption (e.g. Colesca and Dobrica 2008; Liao et 
al.2007; Liu and Zhou 2010) it is discovered as vital determinant of user's satisfaction. We assume that easy to use the LRMIS system would lead the citizen's to be more satisfied with it than its complexity. It then leads towards formulation of the following hypothesis:

H7: Perceived ease of use has a positive and significant impact on user's perceived satisfaction of the LRMIS.

\section{Perceived Ease of Use $\rightarrow$ Behavioral Intention}

Perceived ease of use have a direct impact on behavioral intentions as described in the technology acceptance model (TAM), (Davis et al. 1989).From studies on IS/IT (e.g. Davis et al. 1989; King and He 2006; Venkatesh and Davis 2000) this relation have got a deep empirical evidence support and also in case of e-government adoption (e.g. Hu et al. 2011; Phang et al.2005; Tan et al. 2008; Yao and Murphy 2007). Hu et al. (2011) discussed that when someone exerts less effort in using a new technology, he or she would be more intent to investigate with and use it. Contrary, the hurdle toward using the technology is less, the citizen wish more likely to use it (Hu et al. 2011).In the our research, we assume that citizens would be more tend toward using the LRMIS system when they would trace that using the LRMIS system is more easy and free of complexities .Hence, we hypothesize:

H8: Perceived ease of use has a positive and significant impact on citizen's behavioral intention toward using the LRMIS.

\section{Perceived Ease of Use $\rightarrow$ Perceived Usefulness}

One of the well-established relation of the TAM model is the positive and significant impact of perceived ease of use on perceived usefulness .The causative impact of ease of use on usefulness have a sense considerably, too. If more easy a system is to intervene with, a less effort needed to handle it, and the more effort one can assign to other activities (Radner and Rothschild 1975). This relation in some researches on e-government adoption (e.g. Colesca and Dobrica 2008; Phang et al.2005; Tan et al. 2008) have already empirically justified .Researches on e-government adoption like, Rana et al. (2013a) discovered that the perceived ease of use had a positive and significant impact on perceived usefulness. We hypothesize:

H9: Perceived ease of use has a positive and significant impact on perceived usefulness of the LRMIS.

\section{Perceived Satisfaction $\rightarrow$ Perceived Usefulness}

Discussing perceived usefulness in the individual influence class of the DeLone and McLean model, perceived usefulness is caused by user satisfaction (Rai et al. 2002). Observing the Effect of user satisfaction on 
perceived usefulness, Rai et al. (2002) discovered this relation is positive and significant. In the context of the LRMIS, we assume the fact that higher level of user's perceived satisfaction will direct him to accept that the system will raise his efficiency and overall performance. Contrary, less satisfied citizens might not be concerned toward the re-use of LRMIS system and therefore may not find it that useful. Hence

H10: Perceived satisfaction has a positive and significant impact on perceived usefulness of the LRMIS.

\section{Perceived Usefulness $\rightarrow$ Behavioral Intention}

Considering previous IS studies, the TAM discovered usefulness as one of the noteworthy perceptions leading to intention to adopt new systems (Lee et al. 2003).Studies has discovered that perceived usefulness influences intended adoption of IT (Gefen and Straub 2000).As far as e-government adoption research studies are concerned, this relation has been investigated through the models such as the TAM and extended TAM (TAM2). While investigating 24 total studies in related aspects, it was found significantly important in 21 cases across Various studies (e.g. Hu et al. 2011; Phang et al. 2005; Tan et al. 2008). Meta-analysis of researches related to e-government services adoption also showed that the accumulative effect of perceived usefulness on intention to use as significant (Rana et al. 2012a, b, 2013a,2014).Keeping in mind, the total performance of this relation in area of IS research in general and adoption of e-government research in particular, the following hypothesis can be formulated:

H11: Perceived Usefulness has a positive and significant effect on behavioral intention toward using the LRMIS.

\section{Perceived Risk $\rightarrow$ Behavioral Intention}

Mentioned in old studies, risk perceptions have important influence on use intentions (Fu et al. 2006). Risks associated to information technology are those which show that the system is not sufficiently shielded from different kinds of damages (Straub and Welke, 1998).Perceived risk decreases user's intentions to substitute information and complete transactions (Fu et al.2006; Pavlou 2003; Warkentin and Gefen 2002).

Previous studies on taxpayer's intention to adopt the e-filing system shows that taxpayers were disinclined to file on web if they skeptic about the security of the process (Fu et al. 2006).Perceived risk discovered to impact negatively on user's intention in a lot of researches on e-government adoption (e.g. Fu et al. 2006; Rana et al.2013e; Schaupp and Carter 2010; Schaupp et al. 2010). Hence, we hypothesize:

H12: Perceived risk has a negative and significant impact on behavioral intention toward using the LRMIS. 


\section{Awareness $\rightarrow$ Behavioral Intention}

Awareness is a crucial point in influencing citizen to adopt and use egovernment services. Citizens required perceiving and realizing the advantages of any e-government systems, else they will be uneager and doubtful to use it. Pikkarainen et al. (2004) has found that the amount of information a consumer has about any online service and its advantages may have a crucial effect on the adoption of that service. Some other studies Lee and Chung (2009), Lee et al. (2009) also uses this construct. Hence we hypothesize:

H13: A high awareness of LRMIS has a positive and significant impact on behavioral intention toward using the LRMIS.

\section{Awareness $\rightarrow$ Trust}

Citizen's trust is also associated with their awareness of that egovernment system. Awareness and trust is mutually attached with each other. Some studies Lee and Chung (2009), Lee et al. (2009) also uses these two constructs. Hence we hypothesize:

H14: A high awareness of LRMIS has a positive and significant impact on Citizen's trust on the LRMIS.

\section{Trust $\rightarrow$ Perceived Satisfaction}

Trust is a Critical element for the success e-Government systems, and privacy is the main factor in building citizen's trust in e-Government service (Kim et al., 2009). The more the citizen have trust in e-government services the more they are willing to use them. In order to engage citizens with eGovernment trustfully keeping privacy and security in mind is a better way to maintain a sustainable business relation. Mcknight et al. (2002) in his model of e-commerce customer discussed about trust where they investigated that trusting beliefs would direct to trusting intentions, which in turn impacts trust related behaviors such as commitment loyalty and satisfaction. Lee and Lin (2005) proposed that trust enhancing online purchasing and impact customer attitudes towards buying from t-retailers. Kim et al. (2009) discovered that online customer trust is strongly attached to loyalty in a longitudinal study in the U.S. Hence we hypothesize:

H15: A high trust on LRMIS has a positive and significant impact on Citizen's perceived satisfaction.

\section{Trust $\rightarrow$ Behavioral Intention}

Trust is critical and directly related to behavioral intention of the citizen to use any e-government system. Online system providers are keen to enhance exchange relationships with citizen consumers. Valuable indication for the repetition of mutual exchange relations are citizen's beliefs and 
intentions related to trust in the online system provider (government). Such views rely on the level of risk perceived by citizens and their perceived depth of control on the information that they must exchange with the online service provider (E-Government) (Palvia, 2009). Hence we hypothesize:

H16: A high trust on LRMIS has a positive and significant impact on Citizen’s behavioral intention toward using the LRMIS.

\section{Information Security $\rightarrow$ Trust}

Information security believed to be one of the most critical topics in e-government systems. Security concerns as to keep the citizen customer secure from an incursion of their privacy, influences trust. As security is very much associate to trust, trespassing of security norms may miscalculate and misunderstand while leading to lose customers and negative word- of-mouth (Dixit \& Datta, 2010). Hence we hypothesize:

H17: A high level of Information Security has a positive and significant impact on Citizen's Trust toward using the LRMIS.

\section{Research Methodology}

For the sake of examining e-government system success of LRMIS, we the researchers believed survey as an apropos research method (Cornford and Smithson 1996; Choudrie and Dwivedi 2005). Different kind of method to capture the data, but, a self-administered questionnaire was thought to be a fitted, as a primary survey instrument of data collection in this study. Keeping in mind the fact that this confronts the point of reliability of information by shortening and eliminating the way the questions are asked and given (Cornford and Smithson 1996).In this sense, collecting data from the many of respondents within specific period of time was a captious issue of this research (Fowler 2002).Hence, only closed and multiple-choice questions were added in the questionnaire. The final questionnaire composed of total 50 questions including 10 questions from respondent's demographic background and 40 questions on the 11 different constructs(including dependent variable as Behavioral Intention) of the our proposed research model. All related questions were multiple-type, closed-ended and 7-point Likert scale type. Likert scales (1-7) along with anchors ranging from strongly disagree to strongly agree (Wang and Liao 2008) used for all related non-demographic questions. Appendix-A lists all the items for the constructs used in this study. The sample of the research composed of wide spectrum of respondents from different cities of Pakistan including Lahore, Gujranwala, Gujarat, Sialkot, Faisalabad, Kasoor, Jhelum, and Kharian. Considering previous studies on IS success models, five factors were recognized and a questionnaire to investigate the intention to use and satisfaction was created and pilot were tested with 55 respondents. When the outcomes of the pilot 
test were discovered to be valid and reliable measuring instrument, the scientist resolved that further analysis could minify the set of factors and some further validation endeavors were required (Griffiths et al. 2007). A total of 500 questionnaires were distributed to respondents through different channels. All respondents were exhibited about the functions of the LRMIS given them 3 days' time in some cases while thinking the long list of questions and with a point of thought to give them with a little time to have good understanding of the system, before completing the questionnaire. Some of the questionnaires were advised to complete on spot after the respondents engaged with the systems in a very short period of time. The most respondents were Bachelor degree holders with a good experience of interacting with online systems and other websites, none of them had a previous experience of using the LRMIS. Thinking of their previous educational background and experience of Internet, the shorter time provided to them to familiarize to the system. Total 301 completed survey questionnaires were gotten back. After further inspection of questionnaires 51 of them were partially completed and so rejected from the subsequent analysis. Hence, we were left with 250 usable responses, which made our basis for the empirical analysis for measuring the IS success of LRMIS.

\section{Research findings}

\section{Respondents' demographic profile}

Analyzing demographic data (in Table-2), questionnaire outcomes revealed that the computation of an average respondent's age was found to be 30 years, with males $70.8 \%$ of the sample and $29.2 \%$ were female. The majority of the sample population (i.e., 75\%) appertains to student community with a fair representation from public- and private-sector employees (i.e., $25 \%$ ). Regarding educational qualifications, $85 \%$ of the total sample population is having a minimum degree of graduation. The computer and Internet literacy and awareness of the respondents can be adjudicated from their very high computer and Internet experience percentage $(\approx 97 \%)$. Hence, it is thought that the sample population of respondents would be the best-fit potential users and adopters of the LRMIS.

\section{Reliability analysis - Cronbach's alpha ( $\alpha$ )}

Cronbach's alpha was used to get Reliability analysis. to determine the reliability of the scale, which accommodates an indication about the internal consistency of the items used to measure the same construct (Hair et al. 1992;Zikmund 1994). Cronbach's alpha reliability for all the constructs excluding system quality is in the range $0.768-0.874$, which is very nice (see Table 3). Cronbach's $(\alpha)$ value which is greater than 0.70 is considered to be good (Nunnaly 1978; Hair et al. 1992).Hence, alphas express strong 
reliability for all constructs, but not system quality as it is at satisfactory level.

\section{Descriptive statistics}

In Table 4, we showed the mean and standard deviation (S.D.) for all the 8 constructs and their relevant individual items. High total as well as single item's means for most of the constructs exhibited that participants respond favorably to the all the measures related to IS success and behavioral intention.

Table 2: Cronbach's alpha $(\alpha)$ of constructs

\begin{tabular}{|c|c|}
\hline Construct & Cronbach's Alpha $(\alpha)$ \\
\hline System quality & 0.648 \\
Information quality & 0.801 \\
Service quality & 0.832 \\
Perceived ease of use & 0.768 \\
Perceived usefulness & 0.793 \\
Perceived satisfaction & 0.874 \\
Perceived risk & 0.813 \\
Awareness & 0.791 \\
Trust & 0.811 \\
Information Security & 0.802 \\
Behavioral intention & 0.785 \\
\hline
\end{tabular}

Table 3: Descriptive statistics of the constructs and their items

\begin{tabular}{|c|c|c|c|}
\hline Measure & Item (\#) & Mean & S.D. \\
\hline System quality (SYQ) & 3 & 5.21 & 0.99 \\
Information quality (IQ) & 4 & 5.11 & 1.02 \\
Service quality (SVQ) & 6 & 5.14 & 1.01 \\
Perceived usefulness (PU) & 6 & 5.19 & 0.99 \\
Perceived ease of use (PEOU) & 4 & 5.21 & 1.09 \\
Perceived satisfaction & 4 & 5.22 & 0.98 \\
Perceived risk (PR) & 4 & 4.11 & 1.39 \\
Awareness & 2 & 5.13 & 0.99 \\
Trust & 2 & 5.23 & 1.13 \\
Information Security & 2 & 5.20 & 1.17 \\
Behavioral intention & 3 & 5.29 & 1.23 \\
\hline
\end{tabular}

\section{Hypotheses testing}

Using SPSS 20.0, In Tables 5, 6, 7, 8 and 9 we showed results of linear regression model analyzed. The analysis exhibited in Table 5 supported all the hypotheses (i.e. H8, H11, and H12, H13, H16) on behavioral intention as evidentiary. The constructs PEOU, PU, PR, AW and TR interpret $21 \%$ (adjusted $\mathrm{R}^{2}$ ) of the variance in citizen's behavioral intention of the LRMIS.As the general model is significant, the significance 
of the independent variable was again investigated .Independent variables like PEOU and PU were discovered significant at $(0.0 \%-0.1 \%)$ .significance level except PR, which was discovered negatively significant at $4 \%$ significance level. Hence, all the hypotheses H8, H11, H12, H13 and H16 are well supported. In Table 6 we exhibited the $\beta$-value of independent variables such as PEOU, SYQ, SVQ, IQ, and TR on perceived satisfaction (PS). Model interprets $44.3 \%$ (adjusted $\mathrm{R}^{2}$ ) of the variance in Citizen's satisfaction through the LRMIS. Hence, the generally model was significant and we investigated the significance of each independent variable. The analysis exhibits a stronger impact of PEOU on PS than BI. It shows that the higher ease of use of system leads to stronger citizens' perceived satisfaction than the behavioral intention to actually use it. All quality related constructs as system quality, information quality, and service quality were discovered to be significant on perceived satisfaction at the $0.1 \%$ significance level.

Table 4: Regression coefficients on behavioral intention

\begin{tabular}{|ccccc|}
\hline I.V & $\boldsymbol{\beta}$ & T & Sig. & Results \\
\hline PEOU & $0.221^{* * *}$ & 3.987 & 0.001 & SUPPORTED(H8) \\
& & & & \\
PU & $0.313^{* * *}$ & 6.214 & 0.001 & SUPPORTED(H11) \\
PR & $-0.095^{*}$ & -2.199 & 0.021 & SUPPORTED(H12) \\
AW & $0.322^{* * *}$ & 3.888 & 0.000 & SUPPORTED(H13) \\
TR & $0.313^{* * *}$ & 3.747 & 0.000 & SUPPORTED(H16) \\
\hline
\end{tabular}

I.V. Independent variable, Sig. Significance: ${ }^{*} \mathrm{p}<0.05,{ }^{* *} \mathrm{p}<0.01 ;{ }^{* * *} \mathrm{p}<0.001$

Table 5: Regression coefficients on perceived satisfaction

\begin{tabular}{|ccccc|} 
I.V & $\boldsymbol{\beta}$ & $\mathbf{t}$ & Sig. & Results \\
SYQ & $0.209^{* * *}$ & 3.643 & 0.000 & SUPPORTED(H1) \\
IQ & $0.209^{* * *}$ & 3.799 & 0.001 & SUPPORTED(H5) \\
SVQ & $0.281^{* * *}$ & 5.011 & 0.000 & SUPPORTED(H6) \\
PEOU & $0.111^{*}$ & 2.194 & 0.000 & SUPPORTED(H7) \\
TR & $0.207^{* * *}$ & 3.567 & 0.000 & SUPPORTED(H15) \\
\hline
\end{tabular}

I.V. Independent variable, Sig. Significance: ${ }^{*} \mathrm{p}<0.05,{ }^{* *} \mathrm{p}<0.01 ;{ }^{* * *} \mathrm{p}<0.001$

Hypotheses as H1, H5, H6, and H7 have discovered positive and significant on user's perceived satisfaction. The analysis exhibits that service quality shows the stronger impact on user's perceived satisfaction that other variables such as, system quality (SM), information quality (IQ) and perceived ease of use (PEOU). It shows that citizens would tend to be more satisfied by the patronizes received from the government online services than the information and the system quality and the degree of easiness associated with the LRMIS. Service quality would be associated with the accuracy, 
responsiveness, reliability, technical competence of the government obligated to implement LRMIS. In Table 7, we showed the outcomes of the hypotheses testing on one of the dependent variable perceived usefulness.

Table 6: Regression coefficients on perceived usefulness

\begin{tabular}{|ccccc|} 
I.V & $\boldsymbol{\beta}$ & $\mathbf{t}$ & Sig. & Results \\
IQ & $0.299^{* * *}$ & 6.412 & 0.00 & SUPPORTED(H3) \\
PEOU & $0.409 * * *$ & 9.786 & 0.000 & SUPPORTED(H9) \\
& & & & \\
PS & $0.113^{*}$ & 2.387 & 0.011 & SUPPORTED(H10) \\
\hline
\end{tabular}

I.V. Independent variable, Sig. Significance: ${ }^{*} \mathrm{p}<0.05,{ }^{* *} \mathrm{p}<0.01 ; * * * \mathrm{p}<0.001$

Model exhibits 45.1 \% of variance on citizen user's perceived usefulness from LRMIS. Model was discovered noteworthy with the individual independent variables IQ and PEOU as vital determinants with a significance level of 0.001 and PS at the significance level of 0.04 . Hypotheses H3, H9, and H10 are endorsed and PEOU shows stronger impact on perceived usefulness than IQ and PS .It shows, higher the perceived ease of use of the system higher will be its usefulness as perceived by its citizen users. The relation between perceived satisfactions was discovered noteworthy on perceived usefulness, but not strong enough. In Table 8, the outcomes outline the hypothesis testing results for the dependent variable perceived ease of use. Model shows $46.2 \%$ (adjusted $\mathrm{R}^{2}$ ) of the variance on perceived ease of use. Model on the whole, was discovered significant and we farther tested the importance of each independent variable. Analysis proved that system quality is a stronger reference of perceived ease of use. Information quality was discovered noteworthy on perceived ease of use. It shows that the system architect, analysts and specialists would exercise toward ensuring the quality of the user interface, its documentation, consistency, and maintenance ability of the program code to ensure easy to use system.

Table 7: Regression coefficients on perceived ease of use

\begin{tabular}{|ccccc|} 
I.V & $\boldsymbol{\beta}$ & $\mathbf{T}$ & Sig. & Results \\
SYQ & $0.613^{* * *}$ & 13.989 & 0.000 & SUPPORTED(H2) \\
IQ & $0.111^{* *}$ & 2.689 & 0.005 & SUPPORTED(H4) \\
\hline
\end{tabular}

I.V. Independent variable, Sig. Significance: ${ }^{*} \mathrm{p}<0.05,{ }^{* *} \mathrm{p}<0.01 ;{ }^{* * *} \mathrm{p}<0.001$

Table 8: Regression coefficient on Trust

\begin{tabular}{|ccccc|}
\hline I.V & $\boldsymbol{\beta}$ & $\mathbf{t}$ & Sig. & Results \\
AW & $0.597^{* * *}$ & 7.989 & 0.000 & SUPPORTED(H14) \\
IS & $0.298^{* * *}$ & 2.985 & 0.000 & SUPPORTED(H17) \\
& & & & \\
\hline
\end{tabular}

$\mathrm{R}^{2}=0.43$

I.V. Independent variable, Sig. Significance: ${ }^{*} \mathrm{p}<0.05$, ${ }^{* *} \mathrm{p}<0.01 ; * * * \mathrm{p}<0.001$ 


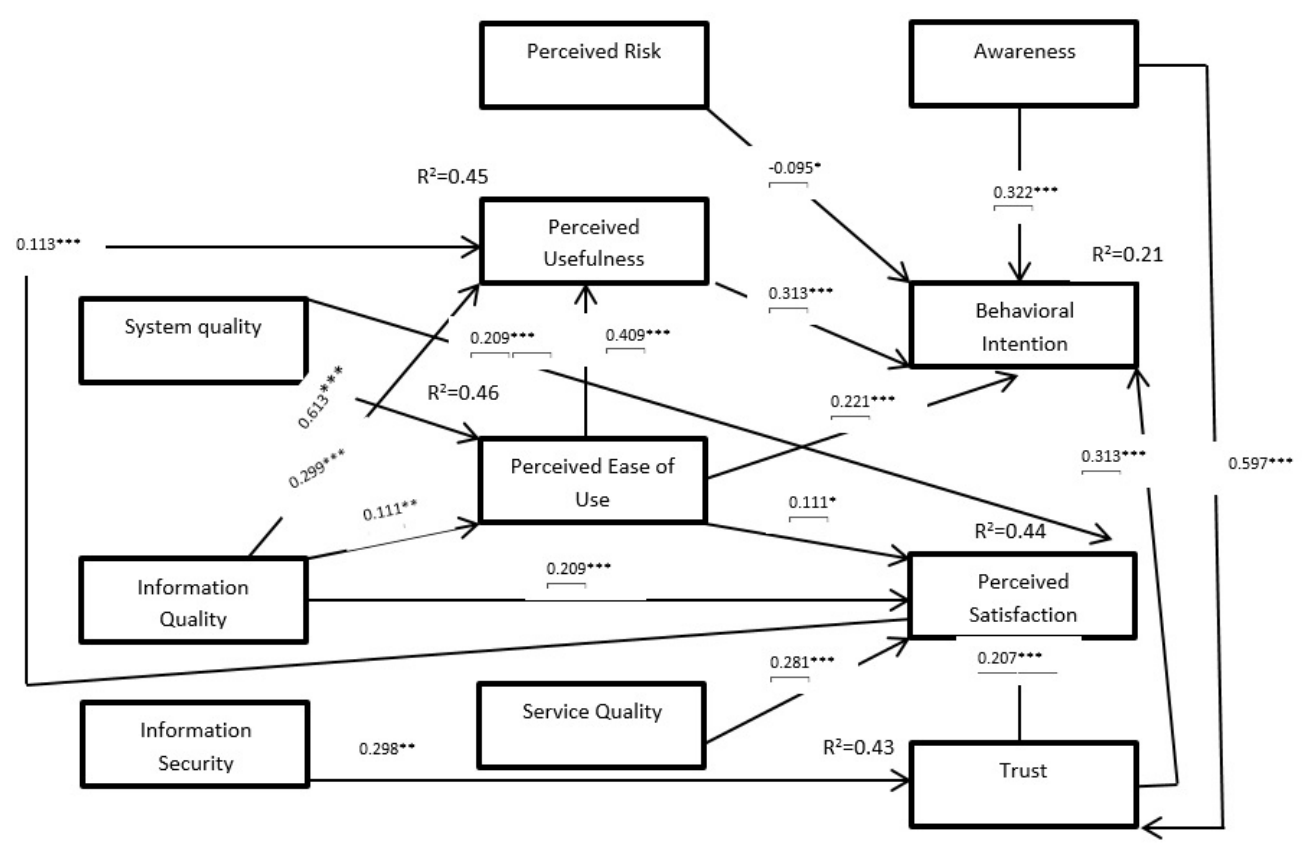

Fig. 2 Validated research model

Fig. 2 Validated research model

In above Fig. 2, Hypothesis testing outcomes of linear regression analysis with the coefficient values (i.e. $\beta$-value), $\mathrm{p}$-value, and $\mathrm{R}^{2}$ - value are presented along the research model.

\section{Discussions}

The intent of this research was to evaluate the success of the LRMIS by designing an e-government specific IS success model. Hence, we added constructs from DeLone and McLean's (2003) and Seddon's (1997) IS success models, to design a model that could interpret the success of the LRMIS, as perceived by the potential citizen users of the system. Hypothesis testing outcomes showed that there are noteworthy relations between the 10 constructs in support to the hypotheses. Regression coefficient results showed that system quality, information quality, service quality, and perceived ease of use are important positive determinants of perceived satisfaction. Perceived usefulness and Perceived ease of use positively impact on behavioral intention, but perceived risk impact negatively on behavioral intention. Variables like perceived ease of use, information quality, and perceived satisfaction discovered to be the noteworthy forecasters of perceived usefulness. Results also exhibited that system quality as the stronger forecaster of perceived ease of use than information quality. It is obvious from the above analytic thinking that perceived ease of use of the system directs the citizen respondents more toward their 
behavioral intentions .In case, as perceived ease of use is discovered as an efficient determinant to determine both behavioral intentions and user satisfaction, it is more noteworthy toward behavioral intentions than satisfaction. Actually, citizen users would lean towards to use the LRMIS system more than being just satisfied to some extent based on the effort-free use of relevant system. Supported by a number of researches using this model, the statement behavioral intentions to use a system is actually based on its perceived ease of use, has already been well described by Davis (1989) through the TAM model .The substantial but negative impact of perceived risk on behavioral intentions shows that the government should serve up adequate security to handle the LRMIS to assure that there is a minimum risk attached to use specific system. E-government online services and websites should have a third party security seals to convey their dedication to security in line with the e-commerce systems as discussed by a number of studies (e.g. Belanger et al. 2002; Ho and Oh 2009). A noteworthy effect of perceived ease of use on user satisfaction has been indorsed by a range of researches (e.g. Colesca and Dobrica 2008; Liao et al., 2007; Liu and Zhou, 2010) attached to the e-government adoption research.

Analytical studies of the quality based determinants and perceived ease of use exhibit that the model interpreted for $44.3 \%$ of the variance in perceived satisfaction. 84\% of the variance in user's perceived satisfaction was analyzed by information quality, system quality, and service quality while only $16 \%$ variance was discussed by perceived ease of use. It shows that quality related constructs are very important factors to manage higher user's perceived satisfaction than simply the effort free use of system. Previous researches (e.g. Floropoulos et al. 2010; Wang and Liao 2008) on the e-government adoption have also recommended the importance of quality related constructs on citizen user's satisfaction. In case of LRMIS is relatively a new system and not being well used by the sample population to discover their land records online and to see other land administered articles attached to it, the stronger significant relationship between perceived ease of use and perceived satisfaction can be expected only when the system in use for a certain period of time. Discussing the system with higher information quality, that is, with more reliable, accurate, complete, relevant, precise, concise, and current information (e.g. Bailey and Pearson 1983; Rai et al. 2002) will accommodate the users with easier to use interface. The higher value of relevant regression weight and important relation between system quality and perceived ease of use indicate that higher system quality of the LRMIS will serve up the user with easier to use application. Constructs such as perceived ease of use, information quality, and perceived satisfaction strongly determines perceived usefulness of the system. Empirical symptoms for the important relation between information quality and perceived 
usefulness is assisted by Seddon's (1997) view of IS success model and important effect of perceived ease of use on perceived usefulness is prompted from the TAM model by Davis (1989). Substantial relations between constructs exhibit that ease to use LRMIS, higher information quality, and perceived satisfaction attached to the LRMIS system will direct to greater citizens' user perceived usefulness. Rai et al. (2002) also discovered a substantial assistance for user satisfaction on perceived usefulness in case of analyzing the validity of the IS success model. We discussed that higher perceived satisfaction toward the LRMIS system would make it more useful for the citizen users of the system. LRMIS has been in service to the Punjab, province of Pakistan. It is being used to handle land record of different types throughout the province.

\section{Conclusion}

Our study is a rescript to a contribute towards the persistence challenge and validation of IS success models in different type of contexts (DeLone and McLean 2003; Rai et al. 2002). The intent of this research is to investigate the success of LRMIS using an integrated IS success model, which is proposed and designed using DeLone and McLean's and Seddon's IS success models .Hence, we incorporated the constructs of these two models and some additional constructs such as perceived risk and perceived ease of use to structure a model that would interpret the success of LRMIS as perceived by speculating responses from the varied levels of potential users of this system from different cities of Punjab Province of Pakistan.

17 hypotheses accomplished importantly as per the suggested hypotheses of the integrated IS success model. Given that it is not a very old system, it is obvious from the empirical results that the implementation of the LRMIS appears to be reasonably successful. It was significant that the government would adopt more drives to increase enhance all quality constructs of the system to captivate more positive responses from the user citizens to their farther sensitization while using the LRMIS system. There would be a focus to spotlight the ease of use and usefulness of the system to improve the citizen user's awareness, promptness, and satisfaction. The government always would try to ensure that the risks attached towards using of the system be minimum.

\section{Limitations and future research directions}

Through the organized cognitive operation that permits us to design and validate success model of e-government based system, current research has few limitations which would be kept in mind while performing future egovernment research. The consideration of an incorporated IS system success model has been formulated in case of to the citizens' users 
perspectives (i.e. (G2C) Government-to-Citizen domain of e-government system).Therefore, the monish required to be considered while generalizing its relevant outcomes to the other classes of users (i.e. in Government-toGovernment (G2G) and Government-to-Business (G2B)) also utilizing this model even in G2Ccontext in other developing country. Moreover, our model does not assess the net advantages as defined in the IS success model (DeLone and McLean 2003; Seddon 1997).Therefore, to measure net advantages from the citizen's user points of view can predict more facets of the system. Future studies require to carefully describing the stakeholders and relevant scenarios under which the net advantages $s$ are to be investigated (DeLone and McLean 2003). The research has not validated LRMIS system under particular geographical and cultural contexts; in future this facet should be investigated. While considering prospective citizen users of this system, this research has accomplished empirical inquiry of the proposed research model the future study can investigate to validate the proposed research model using the data from the existing citizen users of LRMIS system.

\section{Implications for theory and practice}

LRMIS system is examined for the first time using an integrated model of IS systems success using the models of Seddon's (1997) and DeLone and McLean (2003) model, hence this is first theoretical implication of this study. We incorporated additional constructs such as perceived risk and perceived ease of use to grasp efficiently LRMIS's success, with major constructs from Seddon's (1997) and DeLone and McLean's (2003) IS success models. Our suggested integrated model of (LRMIS) IS success presented here can be verified farther on the basis longitudinal data accumulate especially from the employees point of view with whom it was gathered before to observe the pattern how it would improvise later. Final results of the hypotheses attached to the model can assist information system investigator to a comprehensive grasping of citizen's behavioral intention and satisfaction with LRMIS system. Outcomes will also permit egovernment managers and system's architects to envision the factors to pay more attentions to enhance the citizen's satisfaction and behavioral intentions of the system. Important but weaker relation between perceived ease of use and information quality shows that the architect of e-government system should always care appropriately about accuracy, timeliness and relevance of information yielded by the related e-government system. Some real attempt would be made to update the system to prevent any farther embarrassment regarding the utilization of the system. The noteworthy effect $\mathrm{t}$ of perceived usefulness on behavioral intentions shows that in order to increase the adoption of the LRMIS system, the government should effort 
fully to utilize this system and advantageous to its citizens. The policymakers, architect and managers of government require to pay appropriate consideration to enhance the quality criteria of this e-government system LRMIS to increase the citizen's satisfaction.

\section{Appendix-A: Survey items used in this study}

\section{System Quality}

SYQ1: LRMIS would be user friendly.

SYQ2: I would find LRMIS easy to use.

SYQ3: I would find it easy to get LRMIS to do what I would like it to do.

\section{Information Quality}

IQ1: LRMIS would provide sufficient information.

IQ2: Through LRMIS, I would get the information I need in time.

IQ3: Information provided by LRMIS would be up-to-date.

IQ4: Information provided by LRMIS would be reliable.

\section{Service Quality}

SVQ1: LRMIS would provide dependable services.

SVQ2: LRMIS would provide services at the time it promises.

SVQ3: LRMIS would give prompt service to citizens.

SVQ4: LRMIS would be responsive to citizen's request.

SVQ5: LRMIS would be designed with citizen's best interests at heart.

SVQ6: LRMIS would be designed to satisfy the needs of citizens.

\section{Perceived Ease of Use}

PEOU1: Learning to operate LRMIS would be easy for me.

PEOU2: My interaction LRMIS would be clear and understandable.

PEOU3: I would find LRMIS to be flexible to interact with.

PEOU4: It would be easy for me to become skillful at using LRMIS.

\section{Perceived Usefulness}

PU1: Using LRMIS would enable me to observe land records more quickly.

PU2: Using LRMIS would improve my overall performance.

PU3: Using LRMIS would increase my productivity.

PU4: Using LRMIS would enhance my effectiveness.

PU5: Using LRMIS would make it easier to observe land records.

PU6: I would find LRMIS useful in observing land records.

\section{Perceived Risk}

PR1: Use of LRMIS may cause my personal information to be stolen.

PR2: I will feel uneasy psychologically if I use LRMIS. 
PR3: I think it would be unsafe to LRMIS because of the privacy and security concerns.

PR4: I believe that there could be negative consequences by using this LRMIS.

\section{Perceived Satisfaction}

PS1: I feel that LRMIS would adequately meet my needs.

PS2: LRMIS would efficiently fulfill my needs.

PS3: Overall, I would be satisfied with LRMIS.

\section{Awareness}

AW1: I am well aware of LRMIS.

AW2: I think awareness of LRMIS is growing.

\section{Trust}

TR1: I trust fully on LRMIS services.

TR2: LRMIS is a trust worthy e-government system.

\section{Information Security}

IS1: I believe LRMIS is completely secure.

IS2: My land record information is secure in LRMIS.

\section{Behavioral Intention}

BI1: I intend to use LRMIS.

BI2: I predict that I would use LRMIS.

BI3: I plan to use LRMIS in the near future.

\section{References:}

Ahn, T., Ryu, S., \& Han, I. (2007). The impact of Web quality and playfulness on user acceptance of online retailing. Information \& Management, 44(3), 263-275.

Akman, I., Yazici, A., Mishra, A., \& Arifoglu, A. (2005). E-Government:A global view and an empirical evaluation of some attributes of citizens. Government Information Quarterly, 22(2), 239-257.

Bailey, J. E., \& Pearson, S. W. (1983). Development of a tool for measuring and analyzing computer user satisfaction. Management Science, 29(5), 530545.

Belanger, F., Hiller, J. S., \& Smith, W. J. (2002). Trustworthiness in electronic commerce: The role of privacy, security, and site attributes. The Journal of Strategic Information Systems, 11(3), 245-270. 
Carter, L., Schaupp, L. C., Hobbs, J., \& Campbell, R. (2011). The role of security and trust in the adoption of online tax filing. Transforming Government People, Process and Policy, 5(4), 303-318.

Chae, M., \& Kim, J. (2001). Information quality for mobile internet services: A theoretical model with empirical validation. In: Proceedings of the Twenty-second International conference on information systems (pp43-54). New Orleans.

Chai, S., Herath, T. C., Park, I., \& Rao, H. R. (2006). Repeated Use of EGov Web sites: A satisfaction and confidentiality perspective. International Journal of Electronic Government Research, 2(3),1-22.

Chen, C.-W. (2010). Impact of quality antecedents on taxpayer satisfaction with online tax-filing systems-an empirical study. Information \& Management, 47(5), 308-315.

Cheong, J. H., \& Park, M. C. (2005). Mobile internet acceptance in Korea. Internet Research, 15(2), 125-140.

Chiu, C. M., Chiu, C. S., \& Chang, H. C. (2007). Examining the integrated influence of fairness and quality on learners' satisfactionand Web based learning continuance intention. Information Systems Journal, 17(3), 271287.

Choudrie, J., \& Dwivedi, Y. K. (2005). Investigating the research approaches for examining technology adoption issues. Journal of Research Practice, 1(1), Article D1.

Colesca, S. E., \& Dobrica, L. (2008). Adoption and use of e-government services: The case of Romania. Journal of Applied Research and Technology, 6(3), 204-217.

Cornford, T., \& Smithson, S. (1996). Project research in information systems: A Student's guide. London: Macmillan Press Ltd.

Cristobal, E., Flavian, C., \& Guinaliu, M. (2007). Perceived e-service quality (PeSQ): Measurement validation and effects on consumer satisfaction and web site loyalty. Managing Service Quality, 17(3), 317-340.

Davis, F. D. (1989). Perceived usefulness, perceived ease of use, and user acceptance of information technology.MIS Quarterly, 13(3), 318-346.

Davis, F. D., Bagozzi, R. P., \& Warshaw, P. R. (1989). User acceptance of computer technology: A comparison of two theoretical models. Management Science, 35(8), 982-1002.

DeLone, W. H., \& McLean, E. R. (1992). Information systems success: The quest for the dependent variable. Information Systems Research, 3(1), 6095.

Delone, W. H., \& McLean, E. R. (2003). The DeLone and McLean model of information systems success: A ten-year update. Journal of Management Information Systems, 19(4), 9-30. 
Dixit, N., \& Datta, S. K. (2010). Acceptance of e-banking among adult customers:An empirical investigation in India. Journal of Internet Banking and Commerce,15(2).

Dwivedi, Y. K., Williams, M. D., \& Venkatesh, V. (2008). Guest editorial: A pr ofile of adoption of information \& communication technologies (ICT) research in the household context. Information Systems Frontiers, 10(4), 385-390.

Dwivedi, Y. K., Papazafeiropoulou, A., Brinkman, W. P., \& Lal, B. (2010). Examining the influence of service quality and secondary influence on the behavioural intention to change internet service provider. Information Systems Frontiers, 12(2), 207-217.

Dwivedi, Y. K., Kapoor, K. K., Williams, M. D., \& Williams, J. (2013).RFID systems in libraries: An empirical examination of factors affecting system use and user satisfaction. International Journal of Information Management, 33(2), 367-377.

Dwivedi, Y. K., Weerakkody, V., \& Janssen, M. (2012). Moving towards maturity: Challenges to successful e-government implementation and diffusion. The DATA BASE for Advances in Information Systems, 42(4), 11-22.

Floropoulos, J., Spathis, C., Halvatzis, D., \& Tsipouridou, M. (2010).Measuring the success of the Greek taxation information system.International Journal of Information Management, 30(1), 47-56.

Fowler, F. J. (2002). Survey research methods. London: SAGE Publications Inc.

Franz, C. R., \& Robey, D. (1986). Organisational context, user involvement and the usefulness of information systems. Decision Sciences,17(3), 329356.

Fu, J.-R., Chao, W.-P., \& Farn, C.-K. (2006). Acceptance of electronic tax filing: A study of taxpayer intentions. Information \& Management, 43(1), 109-126.

Gefen, D., \& Straub, D. (2000). The relative importance of perceived ease of Use in IS adoption: A study of E-commerce adoption. Journal of the Association for Information Systems, 1(8), 1-28.

Gotoh, R. (2009). Critical factors increasing user satisfaction with egovernment services. Electronic Government, an International Journal, 6(3), 252-264.

Griffiths, J. R., Jhonson, F., \& Hartley, R. J. (2007). User satisfaction as a measure of system performance. Journal of Librarianship and Information Science, 39(3), 142-152.

Gupta, M. P., \& Jana, D. (2003). E-Government evaluation: A framework and case study. Government Information Quarterly, 20(4), 365-387. 
Hair, J. F., Anderson, R. E., Tatham, R. L., \& Black, W. C. (1992). Multivariate data analysis, with readings (3rd ed.). New York: Macmillan Publishing Company.

Ho, B. C. T., \& Oh, K. B. (2009). An empirical study of the use of e-security seals in e-commerce. Online Information Review, 33(4), 655-671.

Hsu, F-M., \& Chen, T-Y. (2007). Understanding information systems usage behavior in E-government: The role of context and perceived value. Pacific Asia Conference on Information Systems, (pp 477-490).

Hu, P. J.-H., Brown, S. A., Thong, J. Y. L., Chan, F. K. Y., \& Tam, K. Y. (2009). Determinants of service quality and continuance intention of online services: The case of eTax. Journal of the American Society for Information Science and Technology, 60(2), 292-306.

Hu, P. J.-H., Chen, H., Hu, H.-F., Larson, C., \& Butierez, C. (2011). Law enforcement officers' acceptance of advanced e-government technology: A survey study of COPLINK mobile. Electronic Commerce Research and Applications, 10(1), 6-16.

Iavari, J. (2005). An empirical test of the DeLone-McLean model of information system success. The Data Base for Advances in Information Systems, 36(2), 8-27.

Ives, B., Olson, M. H., \& Baroudi, J. (1983). Measurement of user information satisfaction. Communications of the ACM, 26(10),785-793.

Jaeger, P. T. (2003). The endless wire: E-Government as global phenomenon. Government Information Quarterly, 20(4), 323-331.

Joo, Y. J., Lim, K. Y., \& Kim, E. K. (2011). Online university students'satisfaction and persistence: Examining perceived level of presence,usefulness and ease of use as predictors in a structural model.Computers \& Education, 57(2), 1654-1664.

Karavasilis, I., Zafiropoulos, K., \& Vrana, V. (2010). Extending TAM to understand E-governance adoption by teachers in Greece. In M.D.

Kang, Y. S., \& Lee, H. (2010). Understanding the role of an IT artifact in online service continuance: An extended perspective of user satisfaction. Computers in Human Behavior, 26(2010), 353-364.

Kim, D. J., Donald, L. F., \& Raghav Rao, H. (2009). Trust and satisfaction, two stepping stones for successful e-Commerce relationships: A longitudinal exploration. Information Systems Research, 20(2), 237-257.

Lee, G., \& Lin, H. (2005). Customer perceptions of e-service quality in online shopping.International Journal of Retail and Distribution Management, 33(2), 161-176.

Lrmis (2015). http://lrma.punjab-zameen.gov.pk/about/lrmis/objectives Lytras, P.O. de Pablos, A. Ziderman, A. Roulstone, H. Maurer, \& J.B. Imber (eds.), (pp 57-68) WSKS 2010, Part II, CCIS 112. 
King, W. R., \& He, J. (2006). A meta-analysis of the technology acceptance model. Information \& Management, 43(6), 740-755.

Kraemer, K. L., Danzinger, J. N., Dunkle, D. E., \& King, J. L. (1993). The usefulness of computer-based information to public managers. MIS Quarterly, 17(2), 129-148.

Lederer, A. L., Maupin, D. J., Sena, M. P., \& Zhuang, Y. (2000). The technology acceptance model and the world wide Web. Decision Support Systems, 29(3), 269-282.

Lee, Y., Kozar, K. A., \& Larsen, K. R. T. (2003). The technology acceptance model: Past, present, and future. Communications of the Association for Information System, 12(1), 752-780.

Liao, C., Chen, J. L., \& Yen, D. C. (2007). Theory of planning behavior (TPB) and customer satisfaction in the continued use of e-service: An integrated model. Computers in Human Behavior, 23(6), 2804-2822.

Liao, Z., \& Cheung, M. T. (2001). Internet-based e-shopping and consumer attitudes: An empirical study. Information \& Management, 38(5), 299-306.

Liu, Y., \& Zhou, C. (2010). A citizen trust model for e-government. In proceedings of IEEE International Conference on Software Engineering and Service Sciences, (pp 751-754).

Maes, A., \& Poels, G. (2007). Evaluating quality of conceptual modeling scripts based on user perceptions. Data \& Knowledge Engineering, 63(3), 701-724.

McGill, T., \& Hobbs, V. (2003). User-developed applications and information systems success: A test of DeLone and McLean's model. Information Resources Management Journal, 16(1), 24-45.

McKnight, D. H., Choudhury, V., \& Kacmar, C. (2000). Trust in ecommerce vendors: A two-stage model. In: Proceedings of the21st International Conference on Information Systems, Brisbane, Queensland, Australia.

Mcknight, D., Choudhury, V., \& Kacmar, C. (2002). Developing and validating trust measures for e-commerce: An integrative typology. Information Systems Research,13(3), 334-359

Nunnaly, J. (1978). Psychometric theory. New York: McGraw-Hill.

Palmer, J. W. (2002). Web site usability, design, and performance metrics.Information Systems Research, 13(2), 151-167.

Palvia, P. (2009). The role of trust in e-commerce relational exchange: A unified model.Information Management, 46, 213-220.

Pavlou, P. (2003). Consumer acceptance of electronic commerce:Integrating trust and risk with the technology acceptance model.International Journal of Electronic Commerce, 7(3), 69-103.

Petter, S., \& McLean, E. R. (2009). A meta-analytic assessment of the DeLone and McLean IS success model: An examination of ISsuccess at the individual level. Information \& Management, 46(3),159-166. 
Petter, S., DeLone, W., \& McLean, E. (2008). Measuring information systems success: models, dimensions, measures, and interrelationships. European Journal of Information Systems, 17(3), 236-263.

Phang, C. W., Sutanto, J., Li, Y., \& Kankanhalli, A. (2005). Senior Citizens’ adoption of E-government. In: Quest of the antecedents of perceived usefulness, 38th Hawaii International Conference on System Sciences, (pp 1-8).

Pikkarainen, T., Pijjarainen, K., Karjaluoto, H., \& Pahnila, S. (2004). Consumer acceptance of online banking: An extension of the technology acceptance model. Internet Research, 14(3), 24-35.

Pitt, L. F., Watson, R. T., \& Kavan, C. B. (1995). Service quality: A measure of information systems effectiveness. MIS Quarterly, 19(2),173-187.

Radner, R., \& Rothschild, M. (1975). On the allocation of effort. Journal of Economic Theory, 10(3), 358-376.

Rai, A., Lang, S. S., \& Welker, R. B. (2002). Assessing the validity of IS success models: An empirical test and theoretical analysis. Information Systems Research, 13(1), 50-69.

Rana, N. P., Williams, M. D., \& Dwivedi, Y. K. (2012a). E-government adoption research: A meta-analysis of findings. In: Proceedings of European Conference of Information Systems, Barcelona.

Rana, N. P., Williams, M. D., Dwivedi, Y. K., \& Williams, J. (2012b). Theories and theoretical models for examining the adoption of egovernment services. e-Service Journal, 8(2), 26-56.

Rana, N. P., Williams, M. D., \& Dwivedi, Y. K. (2012c). Evaluating suitability of alternative theoretical paradigm for examining citizen adoption of e-government (pp. 1-28). London: tGov Workshop,Brunel University.

Rana, N. P., Dwivedi, Y. K., \& Williams, M. D. (2013a). A metaanalysis of existing research on citizen adoption of egovernment. Information Systems Frontiers, 1-17. doi: 10.1007/s10796-013-9431-z.

Rana, N. P., Dwivedi, Y. K., \& Williams, M. D. (2013b). Evaluating the validity of IS success models for the electronic government research:An empirical test and integrated model. International Journal of Electronic Government Research, 9(3), 1-22.

Rana, N. P., Dwivedi, Y. K., \& Williams, M. D. (2013c). Examining the factors affecting intention to use of, and user satisfaction with onlinepublic grievance redressal system (OPGRS) in India. In Y. K.Dwivedi, H. Zinner Henriksen, D. Wastell, \& R. De' (Eds.),Proceedings of IFIP WG 8.6 international conference on transfer and diffusion of IT, TDIT 2013, Bangalore, India, grand successes and failures in IT, public and private sectors (pp. 240-260). Berlin:Springer.

Rana, N. P., Dwivedi, Y. K., \& Williams, M. D. (2013d). E-government adoption research: An analysis of the employee's perspective. 
Rana, N. P., Dwivedi, Y. K., \& Williams, M. D. (2013e). Examining adoption of online pan card registration system: A context of indian egov system. nascent connections. Proceedings of Business School Postgraduate Research Conference, Swansea University, UK.

Rana, N. P., Dwivedi, Y. K., \& Williams, M. D. (2014). A review and weight analysis of the predictors and linkages in electronic government adoption research. International Journal of Indian Culture and Business Management, 8(2), 139-158.

Ranganathan, C., \& Ganapathy, S. (2002). Key dimensions of business-toconsumer web sites. Information \& Management,39(6), 457-465.

Sambasivan, M., Wemyss, G. P., \& Rose, R. C. (2010). User acceptance of a G2B system: A case of electronic procurement system in Malaysia. Internet Research, 20(2), 169-187. Schaupp, L. C., \& Carter, L. (2010). The impact of trust, risk and optimism bias on e-file adoption. Information Systems Frontiers, 12(3), 299-309.

Schaupp, L. C., Carter, L., \& McBride, M. E. (2010). E-file adoption: A study of U.S. taxpayers' intentions. Computers in Human Behavior,26(4), 636-644.

Scott, M., \& DeLone, W. H. (2009). Understanding net benefits: A citizenbased perspective on e-government success. International Conference on Information Systems, (pp 1-11).

Seddon, P. B. (1997). A respecification and extension of the DeLone and McLean model of IS success. Information Systems Research, 8(3),240-253.

Seddon, P. B., \& Kiew, M.-Y. (1994). A partial test and development of the DeLone and McLean model of IS success. In J. I. DeGross, S. L.Huff, \& M. C. Munro (Eds.), Proceedings of the international conference on information systems (pp. 99-110). Atlanta: Association for Information Systems.

Seddon, P. B., \& Kiew, M. Y. (1996). A partial test and development of DeLone and McLean's model of IS success. Australian Journal of Information Systems, 4(1), 90-109.

Sharifi, H., \& Zarei, B. (2004). An adaptive approach for implementing egovernment in I.R. Iran. Journal of Government Information, 30(5),600619.

Straub, D. W., \& Welke, R. J. (1998). Coping with systems risk: Security planning models for management decision making. MIS Quarterly,22(4), 441-469.

Tan, C-W., Benbasat, I., \& Cenfetelli, R. T. (2008). Building citizen trust towards e-government services: Do high quality websites matter?, 41stHawaii International Conference on System Sciences, (pp 1-10).

Teo, T. S. H., Srivastava, S. C., \& Jiang, L. (2008). Trust and electronic government success: An empirical study. Journal of Management Information Systems, 9(3), 99-131. 
Venkatesh, V., \& Davis, F. D. (2000). A theoretical extension of the technology acceptance model: Four longitudinal field studies.Management Science, 45(2), 186-204.

Wang, Y.-S., \& Liao, Y.-W. (2008). Assessing eGovernment systems success: A validation of the DeLone and McLean model of information systems success. Government Information Quarterly, 25(4), 717-733.

Wang, T., Cao, Y., \& Yang, S. (2010). Building the model of sustainable trust in e-government. 2nd IEEE international conference on information and financial engineering, (pp 698-701).

Warkentin, M., \& Gefen, D. (2002). Encouraging citizen adoption of egovernment by building trust. Electronic Markets, 12(3), 157-162.

Warkentin, M., Gefen, D., Pavlou, P., \& Rose, G. (2002). Encouraging citizen adoption of e-government by building trust. Electronic Markets, 12(3), 157-162.

Yao, Y., \& Murphy, F. (2007). Remote electronic voting systems: An exploration of voters' perceptions and intention to use. European Journal of Information Systems, 16(2), 106-120.

Zhang, Z., Leeb, M. K. O., Huanga, P., Zhang, L., \& Huang, X. (2005). A framework of ERP systems implementation success in china: An empirical study. International Journal of Production Economics, 98(1), 56-80.

Zikmund, G. W. (1994). Business research methods (4th ed.). New York: The Dryden Press. 